\title{
Characterization of aging hair and its influence in quality of life
}

\author{
Caracterização do cabelo envelhecido e sua influência na qualidade de vida
}

\author{
Marcella A. L. Gabarra ${ }^{1}$, Gabriela Favaretto ${ }^{1}$, Ana Paula M. Martini ${ }^{1}$ and Patrícia M. B. G. Maia \\ Campos $^{1 *}$
}

${ }^{1}$ Faculdade de Ciências Farmacêuticas de Ribeirão Preto, Universidadede São Paulo, Av. do Café S/N, Monte Alegre, 14040-903, Ribeirão Preto, SP, Brasil

E-mail: pmcampos@usp.br

\begin{abstract}
There are few studies that characterize the non-pigmented hair compared to pigmented hair. Furthermore, it is important to evaluate how the natural process of aging hair influences quality of life in women. For this purpose, a questionnaire was applied to evaluate the impact of greying hair and the appearance alterations on women's self-esteem. The satisfaction level of volunteers regarding their hair structure and conditions such as shine, strength and smoothness were also evaluated. Mechanical properties, such as elasticity and traction to rupture were measured using Universal test equipment. Scanning electron microscopy (SEM) was used to measure the hair surface morphological conditions. A large majority of the volunteers indicated that the beginning of greying hair can negatively influence their quality of life. They also reported that the primary changes of their hair were the frizziness, dryness and loss of shine, increased loss and breakage and thinning. Morphological evaluation showed that the non-pigmented hair cuticles were thinner than pigmented hair. The adherence of the cuticle scales was more pronounced in the non-pigmented hair .Finally, this study showed the influence of the appearance of grey hair on quality of life in women as well as the morphological alterations resulting from the greying processes.
\end{abstract}

Keywords: Ageing hair, UV-Visible Spectrophotometer, Scanning electron microscopy, Force-Stroke test, wellbeing.

\section{Resumo:}

Poucos são os estudos que caracterizam o cabelo não pigmentado em comparação com o cabelo pigmentado. Além disso, é importante avaliar como esse processo natural de envelhecimento capilar influencia na qualidade de vida das mulheres. Para isso, foi aplicado um questionário para avaliar o impacto do aparecimento dos cabelos grisalhos e as alterações que estes causam na auto-estima. Foi avaliado o nível de satisfação das voluntárias com a estrutura dos cabelos e suas condições, tais como brilho, força e suavidade. Foram avaliadas as propriedades mecânicas, tais como elasticidade e tração à ruptura com o equipamento Universal. As condições morfológicas pormicroscopia eletrônica de varredura A maioria das voluntárias relataram que o aparecimento dos cabelos grisalhos influencianegativamente na qualidade de vida e que as principais alterações dos cabelos eram o aumento do frizz, ressecamento, perda de brilho, quebra dos fios e afinamento capilar A avaliação morfológica mostrou que as cutículas do cabelo não pigmentados eram mais finas que as do pigmentado. A adesão das cutículas foi mais pronunciada no cabelo não pigmentado.

Por fim, este estudo mostrou a influência do aparecimento de cabelos grisalhos na qualidade de vida da mulher e as alterações morfológicas que estes processos podem causar nos fios.

Palavras-chave: Cabelo envelhecido, Espectrofotômetro UV-visível, Microscopia eletrônica de varredura, Bem estar. 


\section{Introduction}

The hair is a natural fiber thread formed by $\alpha$-keratin molecules, where two molecules coil to form a $\alpha$-helix structure $^{2}$. It is consists on four layers: cuticle, cortex, intercellular cement and marrow, forming a very rigid structure that gives the thread strength and flexibility, due to the concentration of sulphur from the amino acid cysteine ${ }^{11}$. The current scientific literature includes hair characterization studies from different ethnic groups or groups that have suffered physical and chemical damage ${ }^{4}$. However, there are few studies that characterize the morphological and mechanical properties of the pigmented hair as compared to nonpigmented hair.

Humans carry an inherited genetic code that reflects their hair shape, color, thickness, strength, elasticity and brightness. These characteristics, however, can be modified by environmental conditions and chemical treatments. During the ageing process, the production of free radicals, known for the damage they cause on cellular structures, increases. Defense mechanisms such as antioxidative enzymes and molecules such as vitamin $\mathrm{E}$ decrease ${ }^{10}$, further contributing to the ageing phenotype. Quality of life in our society depends crucially on healthy ageing; a hallmark of it is the greying hair follicle. During the anagen (new hair formation) phase, melanocyte precursors migrate to the hair bulb to form the pigmentary unit, where they mature and synthesize melanin. Melanin is transferred to the hair shaft, forming keratinocytes which give the hair its color ${ }^{3}$. It is well known that, over years, there is a decrease in the activity of tyrosinase, the enzyme responsible for the conversion of tyrosine to melanin, leading to the appearance of grey hair ${ }^{3}$. It is known that an increasingly number of women rely on cosmetics as a means $\mathrm{f}$ raising their self-esteem. Greying hair, one of our most visible and potent ageing sensors, is a natural process of ageing that can negatively influence quality of life in women, often interfering with socio-cultural adjustment. This physical characteristic has been a topic of growing social, economic and cultural interest, due to the concern to maintain a youthful appearance. Therefore, it is necessary to evaluate how this natural process influences the quality of life of women by the investigation of their perception of the alterations that this process can lead in order to develop innovative cosmetics. Hair growth and its disorders, such as changes in hair density or quality, can not only influence the appearance of an individual, but also often lead to a significant emotional load, with low self-confidence, reduced quality of life, and even psychological disorders?

\section{Introdução}

O cabelo é uma fibra natural formada por $\alpha$-queratina em que duas hastes se enovelam formando aestrutura de $\alpha$-hélice ${ }^{2}$. A haste capilar consiste em quatro camadas: cutícula, córtex, cimento intracelular e medula, formada por uma rígida estrutura responsável pela força e flexibilidade do fio, causadas devido às pontes de dissulfeto entre aminoácidos de cisteina ${ }^{11}$.

A literatura cientifica ${ }^{4}$ inclui studos da caracterização de cabelos de diferentes etnias ou que sofreram danos físicos

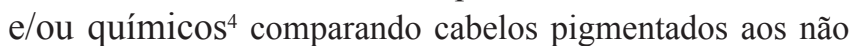
pigmentados.

O código genético reflete na forma do cabelo, cor, espessura, força, elasticidade e brilho, entretanto, essas características podem ser modificadas por condições ambientais e tratamentos químicos. Durante o processo de envelhecimento capilar, a produção de radicais livres, conhecidos pelos danos que causam nas estruturas celulares, aumenta. Os mecanismos de defesa do organismo como, por exemplo, enzimas com efeitos antioxidantes ou moléculas como vitamina $\mathrm{E}$, diminuem, contribuindo para o fenótipo envelhecido ${ }^{10}$.

Durante a fase anágena (formação dos novos fios de cabelo), precursores de melanócitos migram para o bulbo capilar para formar a unidade, aonde são maturados e então sintetizam melanina. A melanina é transferida para a haste capilar formando queratinócitos, os quais dão a cor para os cabelos ${ }^{9}$. Sabe-se que, com o passar dos anos, ocorre uma diminuição da atividade da tirosinase, enzima responsável pela conversão de tirosina em melanina, causando a aparência grisalha aos fios ${ }^{3}$. Com isso, um número crescente de mulheres faz uso de produtos cosméticos de forma a aumentar sua autoestima. $\mathrm{O}$ envelhecimento capilaré um dos maiores sinais do processo de envelhecimento, o qual pode influenciar negativamente na qualidade de vida das mulheres. Assim, essas características têm sido amplamente estudadas devido à preocupação da sociedade em manter a aparência jovem. Portanto, a avaliação da influência deste processo natural na qualidade de vida das mulheres, bem como suas percepções em relação às alterações que este processo pode causar, permite o desenvolvimento de cosméticos inovadores e adequados para esse tipo de cabelo.

O crescimento capilar e suas desordens, como, mudanças na densidade do fio e outras alterações capilares, podem não somente influenciar na aparência do indivíduo, assim como, ocasionar problemas emocionais, baixa autoestima, redução da qualidade de vida e até distúrbios psicológicos ${ }^{6}$.

Além disso, foi reportado ${ }^{3}$ que mudanças hormonais durante a menopausa podem afetar significativamente 
In addition, it has been reported ${ }^{9}$ that hormonal changes that occur during menopause can significantly affect the structure of the hair, including the growth process of hair. It is also known that melanin protects the hair from the effects of ultraviolet radiation ${ }^{8}$. This way, the ageing hair is more sensitive to the daily alterations caused by the environmental damage and may require specific products in order to treat and prevent these particular needs. Currently there are not enough cosmetic products available on the market designed to attend to the needs of this specific population. According to Word Health Organization (WHO), quality of life refers to an individual's perception of their position in the cultural context and social set of values, taking as reference their own aims, expectations, standards and concerns ${ }^{5}$.Considering that Brazil is the second global market in hair care products ${ }^{1}$, hair care represents a social and cultural value that can affect quality of life.

In this context, studies that evaluate the impact of ageing hair and the appearance alterations on women's routine and self-esteem, as well characterize the morphological and mechanical properties of this hair and correlate the structural changes with their impacts on women's routine, are very important to Research and Development of hair care products.

Thus, this study focuses on two main streams of interest: On one hand, the impact of ageing hair on women's self-esteem; On the other, the mechanical and morphological properties, that is, the structural differences of ageing in microscopic and biochemical terms.

\section{Methodology}

\section{Questionnaires}

The questionnaires were applied in one hundred female volunteers, aged between 20 to 60 years. They were interviewed with questions including a) the age of the first appearance of non-pigmented hair; b) if they have noticed hair alterations; c) if so, what kind of alterations were noted; d) the influence of the ageing hair in their quality of life.

\section{Elasticity test}

Samples of 20 threads of pigmented and non-pigmented hair from the same individual, (triplicates) were analyzed using universal test equipment (EMIC DL 2000) in terms of rupture and elasticity modulus ${ }^{12}$.

\section{Scanning Electron microscopy (SEM)}

Samples of non-pigmented and pigmented hair of the same individual (four replicates) were analyzed using a estrutura do cabelo assim como o seu crescimento. Além disso, sabe-se que a melanina exerce um efeito protetor no cabelo contra a radiação ultravioleta ${ }^{8}$. Assim, o cabelo envelhecido (despigmentado) é mais sensível aos danos diários e necessita de produtos especializados a fim de tratar danos específicos visto que o mercado é deficiente em produtos cosméticos que atendam este público específico.

De acordo com a Organização Mundial da Saúde (OMS), a qualidade de vida está diretamente relacionada à percepção individual sobre sua posição no contexto cultural e seus valores sociais, tomando como referência seus próprios objetivos, expectativas, padrões e preocupações ${ }^{5}$. Considerando que o Brasil é o segundo mercado mundial em produtos cosméticos capilare ${ }^{1,}$ o cuidado com os cabelos pode afetar significativamente a qualidade de vida.

Nesse contexto, estudos que avaliem o impacto do envelhecimento capilar e alterações na aparência da fibra, bem como estudos que caracterizem suas propriedades mecânicas e morfológicas correlacionando as mudanças estruturais com o impacto na rotina de mulheres, são de extrema importância para a Pesquisa \& Desenvolvimento de cosméticos capilares.

Portanto, o presente estudo é focado em duas áreas de grande interesse: o impacto do cabelo envelhecido na autoestima de mulheres e suas propriedades mecânicas e morfológicas.

\section{Metodologia}

\section{Questionários}

Os questionários foram aplicados em cem voluntárias do sexo feminino com idade entre 20 e 60 anos. Estas foram entrevistadas sobre a) a idade em que apareceram as primeiras alterações no cabelo não pigmentado; b) se elas perceberam estas alterações; c) se perceberam, quais alterações foram notadas; d) a influência no envelhecimento capilar na sua qualidade de vida.

\section{Teste de elasticidade}

Amostras de 20 fios de cabelo pigmentado e cabelos não pigmentados do mesmo individuo (triplicatas) foram analisadas usando a maquina universal de testes (EMIC DL 2000) analisando os módulos de ruptura e elasticidade ${ }^{12}$.

\section{Microscopia eletrônica de varredura (MEV)}

Amostras de cabelos não pigmentado e pigmentado do 
scanning electron microscopy (EVO 50, Zeiss) in terms of hair thread thickness and circumference, cuticle thickness and adherence of its scales ${ }^{7}$.

\section{Results}

\section{Questionnaires}

The data obtained in the questionnaires applied on more than 100 volunteers showed that the age of the first appearance of non-pigmented hair for $14 \%$ of women interviewed was in their twenties and for $36 \%$ in their fifties (Figure 1). $92 \%$ of the volunteers also reported that appearance of grey hair it can negatively influence the quality of life. In addition, $70 \%$ of the women reported that they were unsatisfied with their hair (Figure 2 ). Considering this, the development of specific cosmetic products to improve hair conditions could have a positive impact in the quality of life.

The volunteers reported that the main observed changes during the ageing process were frizzy hair, dryness and loss of shine, hair loss, followed by an increase of the hair breakage, loss of smoothness, reduced volume and thinner hair (Figure 3). mesmo individuo (quadruplicatas) foram analisadas usando o microscópio eletrônico de varredura (EVO 50, Zeiss) em termos de espessura e circunferência do fio, bem como espessura e aderência das cutículas?.

\section{Resultados}

\section{Questionários}

Os resultados obtidos pela análise dos questionários aplicados em 100 voluntárias mostraram que o inicio do aparecimento dos cabelos não pigmentados foi aos 20 anos, para $14 \%$ das voluntárias e aos 50 para $36 \%$ das voluntárias entrevistadas. (Figura 1). $92 \%$ das voluntariastambém reportaram que o aparecimento dos cabelos não pigmentados pode influenciar negativamente na qualidade de vida. Além disso, $70 \%$ das mulheres reportaram estar insatisfeitas com seus cabelos (Figura 2). Dessa forma, o desenvolvimento de produtos cosméticos específicos para esse tipo de cabelos, pode melhorar as condições dos cabelos e com isso melhorar a qualidade de vida das mulheres.

As voluntárias reportaram que as alterações observadas durante o processo de envelhecimento foram: aumento do frizz, ressecamento dos cabelos, perda de brilho, seguidas por aumento da quebra, perda de maciez, redução de volume e afinamento dos cabelos (Figura 3).

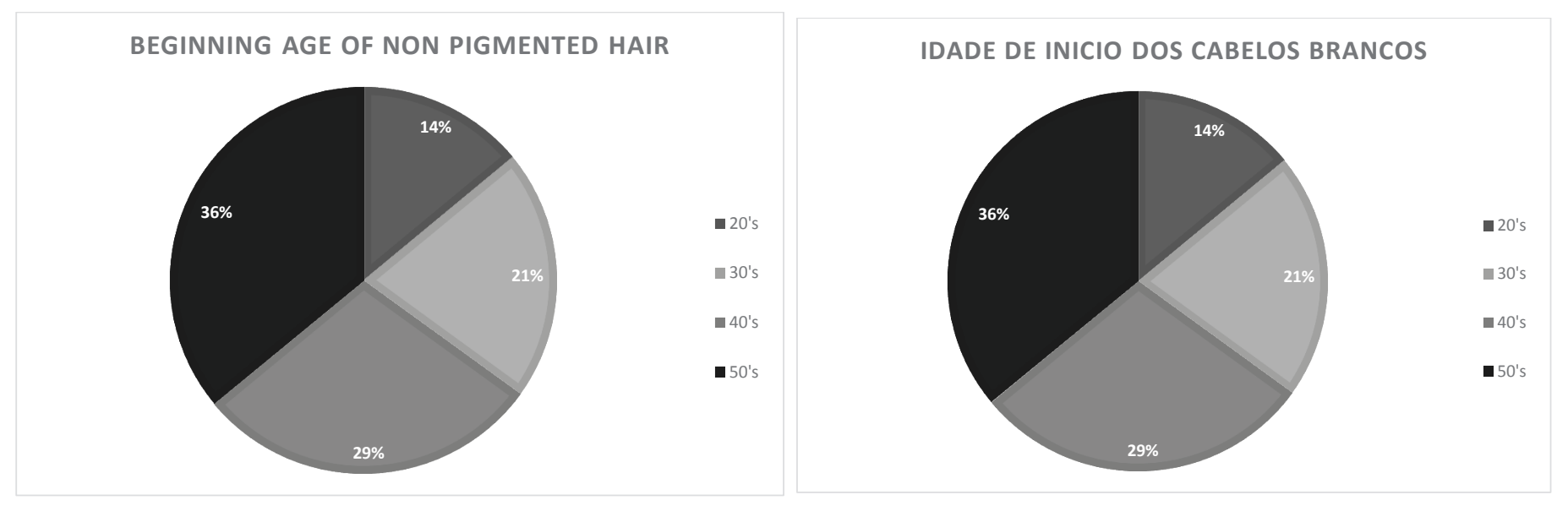

Figure 1/ Figura 1 -Age of first appearance of non-pigmented hair.

Idade de aparecimento dos cabelos brancos. 

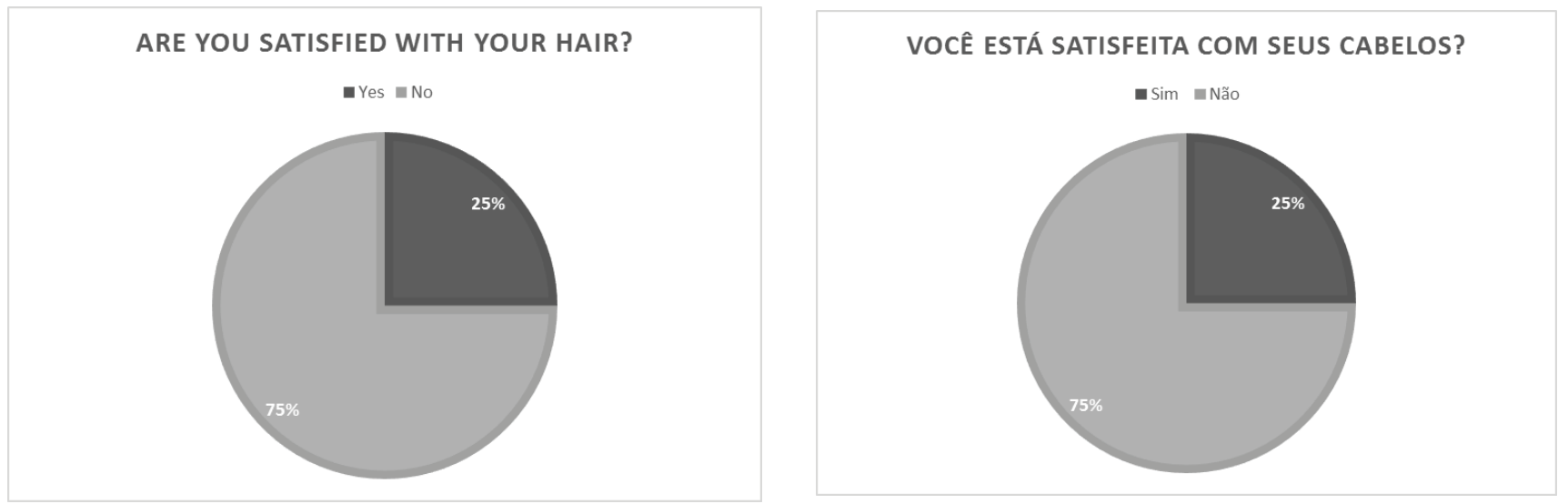

Figure 2/ Figura 2 - Percentage of women unsatisfied with their hair.

Percentagem de mulheres insatisfeitas com os seus cabelos.
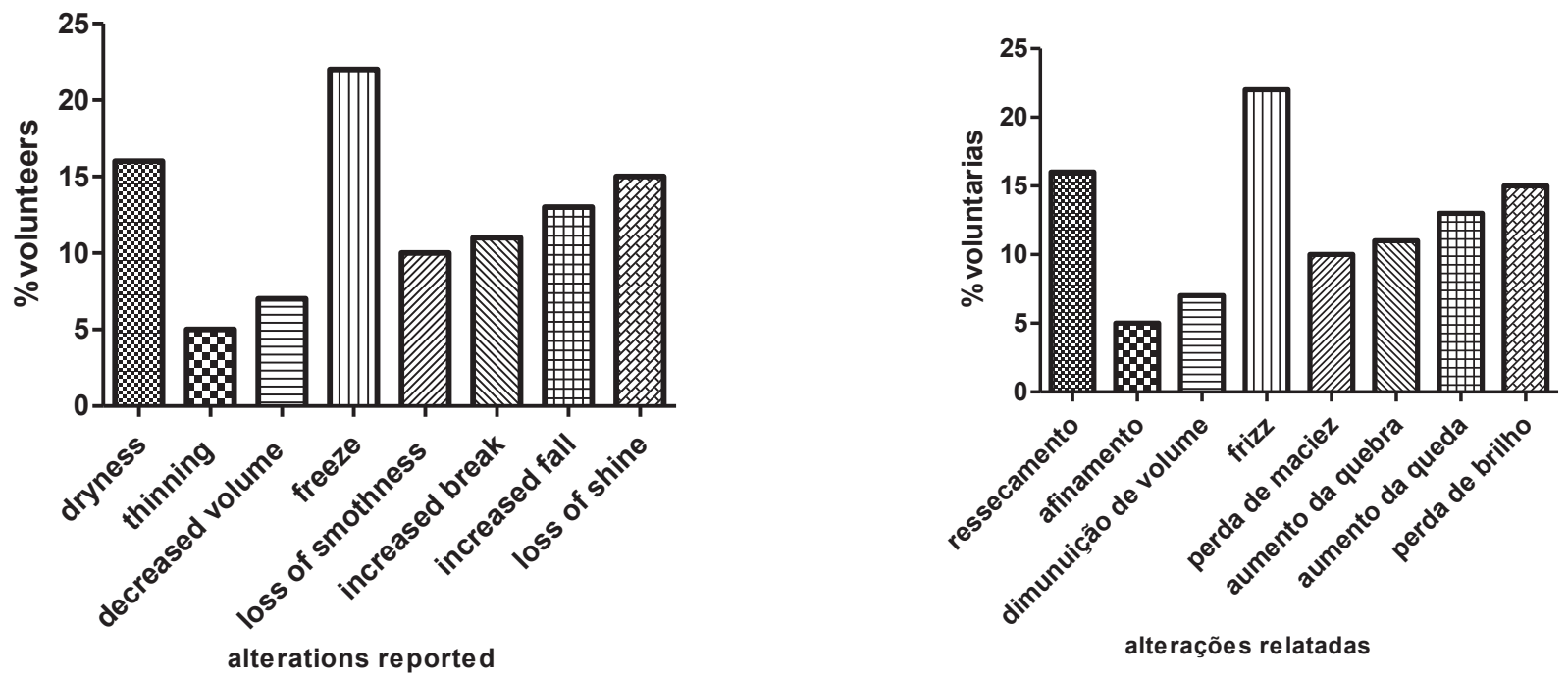

Figure 3/ Figura 3 - Alterations observed with the appearance of ageing hair.

Alterações observadas ao inicio do aparecimento dos cabelos brancos.

The questionnaire answers also indicated that $70 \%$ of the volunteers believe that women who do not use dye to cover the grey hair present bad temper and lack of vanity, for example, women who don't use make up, don't smile, and $30 \%$ believe that those women also seem older and less attractive than in reality.

If forced to choose, the volunteers indicated that they would choose the hair care rather than skin care products, showing the importance of the appearance of the hair in their quality of life.

Finally, the questionnaires showed that $89 \%$ of the women believe that products for hair can affect their
Os resultados obtidos pela analise dos questionários também indicaram que $70 \%$ das voluntarias acreditam que mulheres que não usam tintura para colorir os cabelos envelhecidos apresentam fisionomia mal humorada, sem vaidade e $30 \%$ acreditam que essas mulheres parecem mais velhas e menos bonitas do que realmente são. Se tivessem que escolher entre o tratamento dos cabelos ou o tratamento da pele, as voluntarias indicaram que escolheriam o tratamento dos cabelos, mostrando a importância da aparência dos cabelos para a qualidade de vida das mulheres.

Finalmente, os resultados obtidos pela analise dos questionários mostraram que $89 \%$ das mulheres acre- 
quality of life (Figure 4). This is an indication of how these alterations are negatively perceived by the women when the appearance of the grey hair occurs.

From chemical treatments to plastic surgeries, it seems there is no limit to the attempts of women to maintain a youthful appearance. Chemical changes in order to improve their appearance, however, can cause damages to the hair structure. ditam que produtos para o tratamento dos cabelos podem afetar a sua qualidade de vida (Figure 4). Dessa forma, é notável como essas alterações nos cabelos são negativamente percebidas pelas mulheres quando o seu aparecimento ocorre.

Dos tratamentos químicos a cirurgias plásticas, não existem limites para a mulher que tenta manter a aparência jovem. Alterações químicas, feitas para melhorar a aparência dos cabelos, entretanto, causam diversos danos na estrutura capilar.
DO YOU BELIEVE THAT THE USE OF COSMETICS CAN INFLUENCE YOUR QUALITY OF LIFE ?

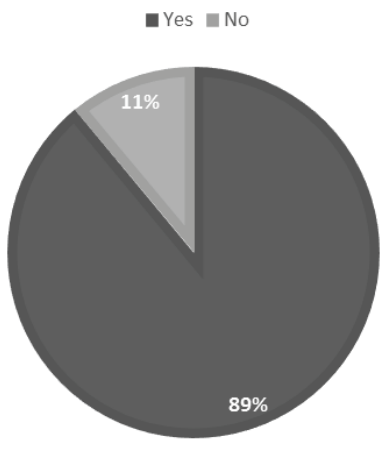

VOCÊ ACREDITA QUE O USO DE COSMETICOS PODE INFLUENCIAR NA SUA QUALIDADE DE VIDA?

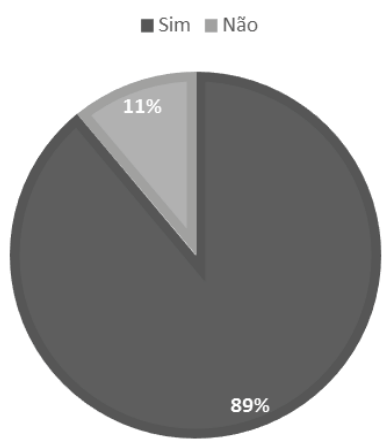

Figure 4/ Figura 4 - Percentage of women who believe that the use of cosmetics for hair care can influence in their quality of life.

Porcentagem de mulheres que acreditam que o uso de produtos cosmeticos podem influenciar na qualidade de vida.

\section{Mechanical and morphological study}

The morphological evaluation of hair surface showed that the non-pigmented hair cuticles were significantly thinner than the pigmented hair (Figure 5).

It was also observed that the adherence of the cuticle scales was more pronounced in the non- pigmented hair (Figure 6).

The evaluation of the mechanical properties showed that non-pigmented hair exhibits a higher elastic and rupture modulus when compared to pigmented hair (Figure 7).

The force/stroke graph showed that the pigmented hair requires less rupture strength and presents a higher elastic modulus than the non-pigmented hair. Thus, the non-pigmented hair is on one hand is stronger than pigmented hair, while on the other, the absence of melanin contributes to increase the negative effects reported by the volunteers. The results obtained in the morphologi-
Estudo das propriedades morfologicas e mecânicas.

A análise morfológica das propriedades dos cabelos mostrou que as cutículas dos cabelos não pigmentados são significativamente mais finas do que as cutículas dos cabelos pigmentados (Figura 5).

Também foi observado que a aderência das cutículas foi mais pronunciada no cabelo não pigmentado (Figura 6). A avaliação das propriedades mecânicas mostrou que o cabelo não pigmentado exibe um modulo elástico e de ruptura maior quando comparado ao cabelo pigmentado (Figure 7)

O gráfico de tensão/deformação mostrou que o cabelo pigmentado requer menor módulo de ruptura e apresenta modulo elástico maior do que o cabelo não pigmentado. Entretanto, o cabelo não pigmentado, por um lado se apresenta mais forte que o cabelo pigmentado, contudo, a ausência de melanina contribui para o aumento dos efeitos negativos reportados pelas voluntarias. Assim, os resultados obtidos na análise morfológica dos 
cal and physical analysis of the properties of the hair were thus complementary to the study of the perception of those alterations by the panelists.

The results obtained in the SEM analysis showed a higher adherence of the cuticle scales, potentially justifying the fact that the non-pigmented hair was stronger than the pigmented hair. However, this is not a significant protection against chemicals and external aggressions once melanin is lost. It is an important alteration that significantly influences in the properties and protection of the hair, as were noticed by the panelists ${ }^{8}$. fios e a análise das propriedades físicas e mecânicas dos mesmos, foi complementar ao estudo de percepção destas alterações pelas voluntárias do estudo.

Os resultados obtidos pela análise no microscópio eletrônico de varredura (MEV) mostrou uma aderência maior das cutículas, que pode justificar o fato do cabelo não pigmentado se apresentar mais forte do que o cabelo pigmentado. Contudo, não apresenta uma proteção significante ao cabelo contra agressões químicas e do meio ambiente, uma vez que a melanina é ausente. É uma alteração importante que influencia significativamente nas propriedades, bem como na proteção do fio, o que foi relatado pelas voluntarias ${ }^{(8)}$.
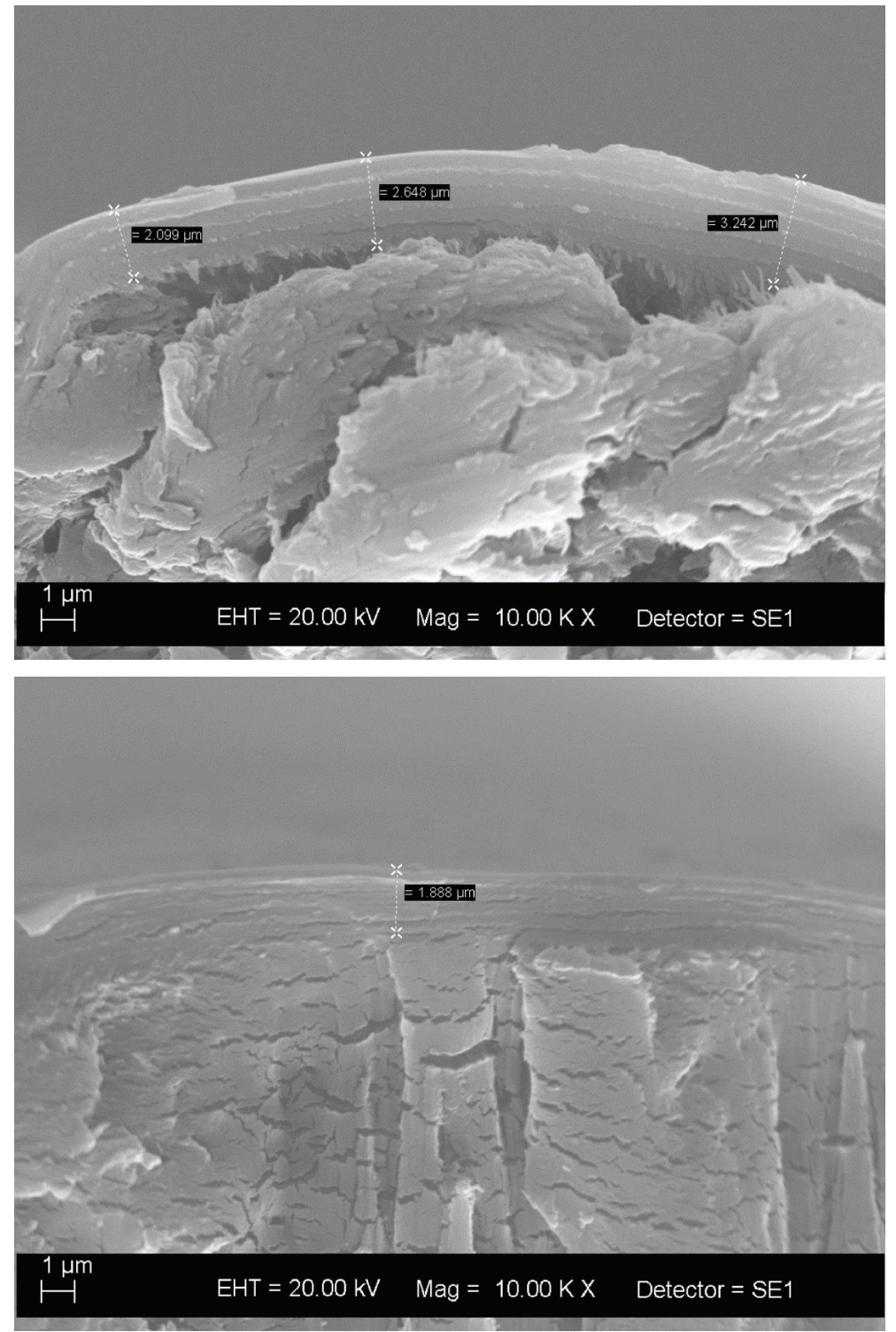

Figure 5/ Figura 5 - SEM photomicrograph of single strands from the same individual. In (A) a sample of pigmented hair and in (B) a sample of nonpigmented hair of a cross-section showing the horizontal view of the thickness of the hair $(10000 \mathrm{x})$.

Análise de microscopia eletrônica de varredura (MEV). Em (A) a amostra de cabelo pigmentado e em (B) a amostra de cabelo não pigmentado em corte horizontal mostrando a parte interna do fio e sua espessura

$(10000 \mathrm{x})$. 

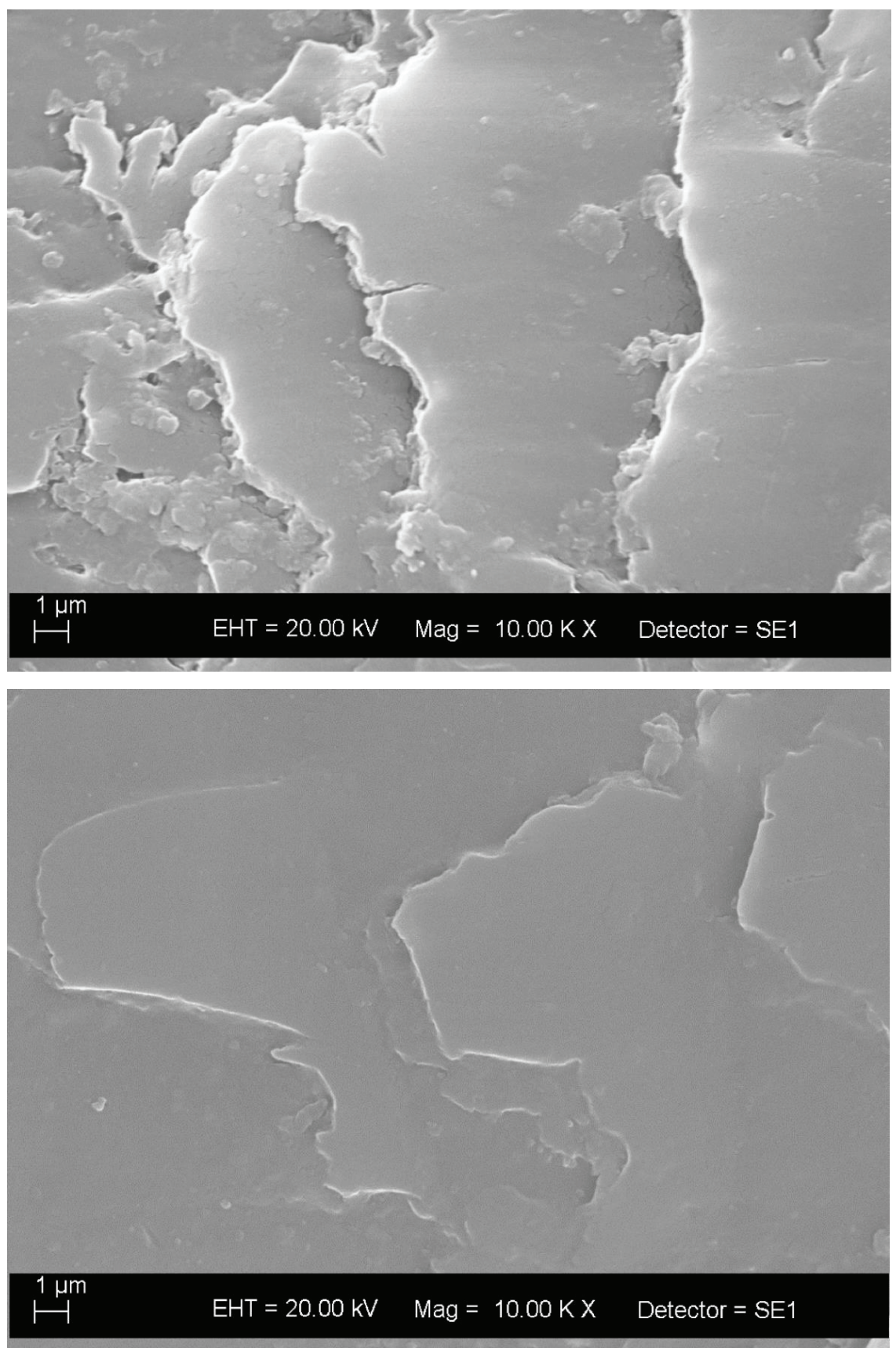

Figure 6/ Figura 6 - SEM photomicrograph of single strands from the same individual. In (A) a sample of pigmented hair and in (B) a sample of non-pigmented hair, showing the adherence of the cuticle scales $(10000 \mathrm{x})$.

Analise microscópica feita no MEV.Em (A) a amostra de cabelo pigmentado e em (B) a amostra de cabelo não pigmentado, mostrando a aderência das cutículas $(10000 \mathrm{x})$. 

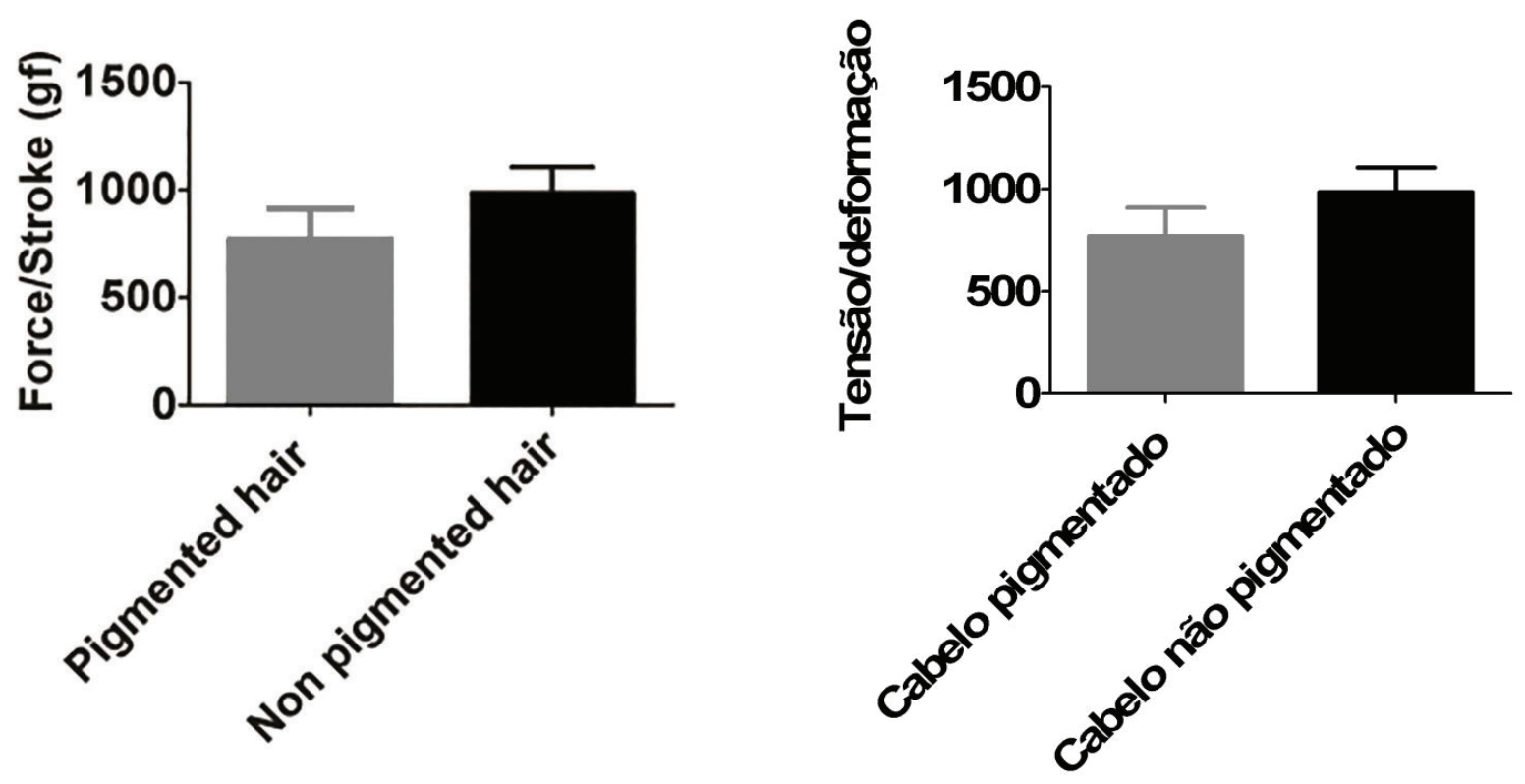

Figure 7/ Figure 7 - Bar graph of the force/stroke values of pigmented and non-pigmented hair (Mann Whitney - Unpaired t test). * $(p \leq 0.05)$.

Gráfico de barras dos valores de tensão/deformação dos cabelos pigmentado e não pigmentado (Mann Whitney - Unpaired t test). ${ }^{*}(p \leq 0.05)$.

\section{Discussion}

Concerning the characterization of morphological and mechanical properties of non-pigmented hair, the results suggests that non-pigmented hair presents some differences that also were reported by the panelists on the questionnaires. As mentioned previously, they reported that the ageing process of the hair causes some unpleasant changes such as frizzy hair, dryness and loss of shine, hair loss, followed by an increase of the hair breakage, loss of smoothness, reduced volume and thinning hair. Also they reported that, in their opinion, women who do not use dye to cover their grey hair are usually bad tempered and lack of vanity, seeming older and less attractive than they really are.

Thus, the data showed that the appearance of grey hair negatively influences the quality of life of women and only a small percentage of women are satisfied with their hair appearance.

\section{Conclusion}

Studies that evaluate the satisfaction level of their hair in parallel with characterization studies are important for $R \& D$ of cosmetics for hair care that meet the real needs of the consumer.

\section{Discussão}

No que tange a caracterização das propriedades morfológicas dos cabelos, os resultados sugerem que o cabelo não pigmentado apresenta diferenças que foram também reportadas pelas voluntarias na analise dos questionários. Como mencionado anteriormente, foi reportado que o processo de envelhecimento causa mudanças consideradas desagradáveis nos cabelos, como o aparecimento de frizz, ressecamento dos fios, perda de brilho, aumento da queda, seguidos por aumento da quebra, perda de maciez, redução de volume e afinamento da fibra capilar. Além disso, foi relatado, que na opinião das voluntarias, mulheres que não usam tintura nos cabelos não pigmentados, aparenta, mal humoradas e sem vaidade, principalmente mais velhas e menos atraentes do que realmente são. Assim, o resultado obtido na analise dos questionários mostra que a aparência dos cabelos envelhecidos influencia negativamente na qualidade de vida da mulher e apenas uma pequena porcentagem das mesmas está satisfeita com a aparência dos seus cabelos.

\section{Conclusão}

Estudos que avaliam o nível de satisfação dos cabelos em paralelo com estudos de caracterização são de extrema importância para a $\mathrm{P} \& \mathrm{D}$ de produtos cosméticos para o tratamento dos cabelos que atendam as necessidades do consumidor. 
Considering that $75 \%$ of women surveyed were not satisfied with their hair and $89 \%$ of the women believe that the use of cosmetics can affect their quality of life, the use of appropriate product for hair care impacts directly on a woman's well-being and quality of life. Furthermore, the women in this study reported a lack of specific products in the market that attend their real needs.

This way, these studies contribute to the development of products that attend the real needs of the women that are also safe and effective. Thus, the present study allows the development of cosmetics that can improve the health and beauty of hair as well as preventing the daily aggressions that hair suffers. Such cosmetics could also enable the promotion of wellness and improve the quality of life and well being of women, who are the main consumers of hair care products.

\section{Acknowledgment}

The authors thank Pró Reitoria de Cultura e Extensão Universitária from University of São Paulo for granting financial support for this study.

\section{Conflict of Interests}

The authors declare that there are no financial and/or personal relationships that could be viewed as presenting a potential conflict of interests.
Considerando que $75 \%$ das mulheres questionadas não estão satisfeitas com os seus cabelos e $89 \%$ das mulheres acreditam que o uso de produtos cosméticos adequados pode afetar a sua qualidade de vida, o uso do produto cosmético adequado para o tratamento dos cabelos impacta diretamente no bem estar da mulher, bem como na sua qualidade de vida. Além disso, as mulheres reportaram a falta de um produto cosmético especifico que atenda a suas reais necessidades.

Assim, os resferidos estudos contribuem para o desenvolvimento de produtos que atendam as reais necessidades das mulheres, que sejam seguros e eficazes. Assim, o presente estudo permite o desenvolvimento de produtos cosméticos que possam melhorar a saúde e beleza dos cabelos, bem como prevenir as agressões diárias que os cabelos sofrem. Tais cosméticos podem promover o bem estar e qualidade de vida da mulher, que são as maiores consumidoras de produtos para os cuidados dos cabelos.

\section{Agradecimentos}

Os autores agradecem a Pró Reitoria de Cultura e Extensão Universitária da Universidade de São Paulo pelo apoio financeiro ao projeto.

\section{Conflito de Interesses}

Os autores declaram a inexistência de qualquer tipo de relação financeira ou pessoal que possa representar um potencial conflito de interesses. 


\section{References/ Referências}

1. ABIHPEC - Associação Brasileira de Industrias de Higiene, Perfumaria e Cosméticos Web site, available at http://www.abihpec. org.br/2014/09/brasil-detem-26-do-mercado-mundial-de-condicionadores/ Access in October 09, 2014.

2. Berivan E, Havitciogluu H, Aktan S, Karaus $\mathrm{N}$. Biomechanical properties of human hair with different parameters. Skin research and Technology 2008; 14: 147-151.

3. Choi HI, Choi GI, Kim EK, Choi YJ, Sohn KC, Lee Y, Kim CD, Yoon TJ, Sohn HJ, Han SH, Kim S, Lee JH, Lee YH. Hair greying is associated with active hair growth. British Journal of Dermatology 2011; 165: 1183-1189.

4. Dagama RM. Avaliação do dano a haste capilar ocasionado por tintura oxidativa aditiva ou não de substancias condicionadoras. Published thesis (MSc), University of São Paulo, 2010 .
5. Fleck MPA. O instrumento de avaliação de qualidade de vida da Organização Mundial Da Saúde : características e perspectivas. ABRASCO - Associação Brasileira de Pós Graduação em Saúde Coletiva 2000; 5(1): 33-38.

6. Harth W and Blume-Peytavi U. Psychotrichology: psychosomatic aspects of hair diseases. J Dtsch Dermatol Ges 2013; 11(2):125-35.

7. Nogueira A, Joekes I. Hair color changes and protein demage caused by ultraviolet radiation. Journal of Photochemistry and Photobiolog 2003; 74: 109-117.

8. Nogueira AS, Nakano AK, Joekes I. Impairment of hair mechanical properties by sun exposure and bleaching treatment. J Cosmet Sci 2004; 55: 533 - 537.
9. Peters EM, Imfeld D, Graub R. Graying of the human hair follicle. J Cosmet Sci 2011; 62(2):121-5.

10. Ralph M, Trueb. Oxidative Stress in Ageing of Hair. International Journal of Thricology 2009; 1(1): 6-14

11. Velasco MVR, Dias TC, Freitas AZ, Vieira ND, Pinto CASO, Kaneko TM, Baby AR. Hair fiber characteristics and methods to evaluate hair physical and mechanical properties. Brazilian Journal of Pharmaceutical Sciences 2009; 41, (1): 153-162.

12. Wagner RCC, Joekes I. Hair protein removal by sodium dodecyl sulfate. Journal of Photochemistry and Photobiology 2005; 41: 7-14. 